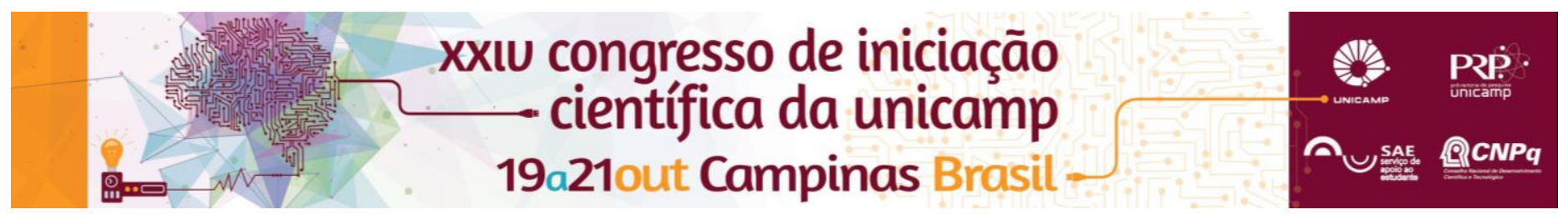

\title{
Análise comparativa das ocupações e dos salários feminino e masculino no mercado de trabalho.
}

\section{Carlos Salas Paez, Beatriz Adorno Brolacci*}

\section{Resumo}

O trabalho busca contribuir com o debate acerca das desigualdades entre homens e mulheres no mercado de trabalho, seja quanto às questões salarial ou ocupacional.

Partindo de duas visões da economia (neoclássica e política) sobre a discriminação no mercado de trabalho, a pesquisa busca mostrar as causas de uma persistente divisão sexual do trabalho e de uma duradoura desigualdade salarial.

\section{Palavras-chave:}

Trabalho feminino, desigualdade salarial, divisão sexual do trabalho.

\section{Introdução}

A literatura econômica fornece duas abordagens distintas para a interpretação da discriminação sexual no mercado de trabalho: economia neoclássica e economia política.

Na medida em que a corrente neoclássica analisa o problema do ponto de vista da oferta e procura nos mercados, ela concentra sua explicação nas ações discriminatórias individuais, em suas implicações para o mercado e na chamada Teoria do Capital Humano.

Em contrapartida, a visão política, embasada, majoritariamente, em ideais marxistas, avaliará a discriminação partindo de comportamentos coletivos, da interação de forças políticas, econômicas e sociais e não somente da influência das forças de mercado como o fez a teoria neoclássica.

Apesar das tentativas de explicações da discriminação por parte dessas duas vertentes econômicas, essa discriminação, a princípio, não fez qualquer tipo de referência às mulheres. Ademais, até a década de 1960, as mulheres eram nitidamente desconsideradas de modelos econômicos, salvas raras exceções de referências ao grupo.

Contudo, as desigualdades salariais derivadas de gênero são verificadas, atualmente, em quase todas as categorias profissionais.

\section{Resultados e Discussão}

No Brasil, a Pesquisa Nacional por Amostra de Domicílios (Pnad) do IBGE, de 2012, mostrou que o salário das mulheres correspondeu a $72,9 \%$ do rendimento masculino para o mesmo ano, analisando-se o cálculo médio mensal do salário para ambos os gêneros. Além disso, considerando o mesmo período, $23,7 \%$ dos homens empregados recebiam até um salário mínimo, ao passo que para as mulheres, esse percentual atingia 33,3\%.

A análise de dados das remunerações femininas e masculinas para o Brasil, nos últimos anos, nos permite verificar a baixa adequação da Teoria do Capital Humano para se explicar a diferença salarial entre os gêneros. Tal teoria justifica, apenas, uma baixíssima parcela das discriminações salarial e ocupacional verificadas no mercado de trabalho. Grande parte das desigualdades de salários verificadas entre homens e mulheres tem causas sociais e raízes históricas, impossíveis de se solucionarem somente pelo mercado.
Além da desigualdade salarial, é nítida também a segregação ocupacional. Apesar da ampliação da participação feminina em uma série de atividades econômicas, a inserção da mulher permanece, na grande maioria dos casos, vinculada a setores tradicionalmente destinados a elas.

Em 2014, as mulheres ultrapassaram pela primeira vez o patamar de $70 \%$ da renda masculina. Entretanto, as mulheres negras não chegaram, ainda, a alcançar nem $40 \%$ da renda dos homens brancos. ${ }^{1}$ Assim sendo, apesar do movimento de redução do gap salarial entre homens e mulheres, esta evolução se dá de forma ainda muito lenta e desigual, o que não altera de maneira definitiva a estrutura da desigualdade salarial entre gêneros no mercado de trabalho.

Figura 1. Razão entre as rendas do trabalho principal da população ocupada de 16 anos ou mais de idade, segundo sexo e raça/cor. Brasil, 2004 a 2014

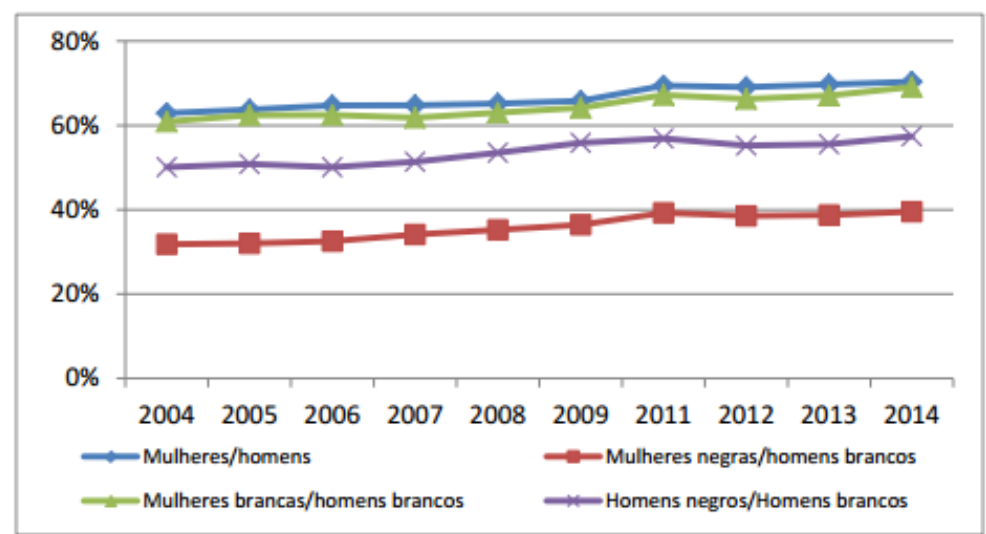

Fonte: Pnad/IBGE Elaboração: IPEA/DISOC/NINSOC Núcleo de Gestão de Informações Sociais

\section{Conclusões}

Todo esse quadro revela a enorme necessidade e a importância do debate acerca do problema da desigualdade entre homens e mulheres no mundo do trabalho, seja esta em nível ocupacional ou salarial.

${ }^{1}$ Pinheiro, L. S.; Lima Junior, A. T.; Fontoura, N. e Silva, R. A

Mulheres e trabalho: breve análise do período 2004-2014. 2016 